\title{
A Questionnaire is Designed To Determine the Requirements and Expectations of Job Seekers in their Industry
}

\author{
Sheng Wang ${ }^{1}$, Yiwei Zhao ${ }^{2}$ \\ ${ }^{1}$ College of Professional Studies, Northeastern University, Boston02115, Massachusetts, America \\ ${ }^{2}$ School of Statistics, Shanxi University of Finance and Economics, aiyuan030000, Shanxi, China \\ *Corresponding author
}

Keywords: Multiple regression; Factor analysis; Talent introduction

\begin{abstract}
In the economic development indicators, the sustained economic growth rate reflects the economic vitality of a city and is closely related to the potential demand for talents. Only with continued economic growth can new employment opportunities be continuously increased. The higher the sustained economic growth rate, the more new employment opportunities and the stronger the attractiveness of talents, and the lower the sustained economic growth rate, the fewer new employment opportunities and the worse the attractiveness of talents. Therefore, we try to evaluate talent introduction programs by constructing indicators to provide suggestions for positive internal testing related to talent introduction. First, find relevant data, establish a mathematical model based on relevant literature and corresponding data, and quantify and analyze the Shenzhen talent introduction plan with the plan of "Several Measures to Strengthen the Business Environment Reform" issued by Shenzhen[1]. After that, all the indicators were used as comprehensive indicators using the factor analysis method, that is, six comprehensive indicators such as economic development level, living environment status, social security management, education level, natural environment status, and technological innovation atmosphere. Finally, we integrate the various indicators, and the multiple regression method is used to regress each influencing factor to obtain quantitative results. It is combining relevant measures and policies to provide targeted suggestions for talent introduction programs.
\end{abstract}

\section{Introduction}

We designed a questionnaire to determine the requirements and expectations of job seekers in their industry. Add in absolute (industry) and relative (region, purchasing power parity) income judgments, and finally use factor analysis to extract the leading indicators of environmental factors (i.e., security, traffic, pollution, education, health care, shopping) to represent the impact of environmental factors. The ratio of individual expectations to actual enterprise expectations is used as an indicator to describe the ideal, needs, and aspirations of talents and this indicator also takes into account the actual future development prospects. Finally, we established a model for evaluating talent attraction. After analyzing the results and adjusting the model, the final evaluation model is determined.

\section{Data Source and Preprocessing}

By searching relevant data on the official website of the bureau of statistics and other database data, the data of corresponding indicators can be found after integrated analysis. And then the data analysis. In the process of data analysis, different algorithms have different requirements on data types, so the corresponding data types need to be converted to fit different analysis methods. The collected initially data are often lack, redundancy, non-standard, logic unreasonable, and other conditions, so in order to better practical data analysis, it is necessary to preprocess the original data, with relevant knowledge as a guide, to improve the efficiency and accuracy of data analysis. 


\section{Modeling}

\subsection{Factor analysis method for a comprehensive evaluation of the environment}

Factor analysis is a multivariate statistical analysis method that studies the internal dependence of variables and reduces some variables with complicated relationships to a few comprehensive factors[2]. The basic idea of this method is to classify the observation variables and classify the ones with high correlation, that is, those closely related to each other, into the same category. In contrast, the correlation between variables of different categories is low. Then, each category of variables represents a basic structure, that is, common factors. The problem under study is to try to describe each component of the original observation by the sum of the least number of unmeasurable linear functions of the so-called common factors and the specific factors.

\subsection{Adaptability analysis of factor analysis in environmental evaluation}

In this paper, the factor analysis in SPSS16.0 software is used to evaluate the environment. Factor analysis studies how to condense many original variables into a few factors with minimum information loss, which can significantly reduce the number of variables in data modeling. Factor analysis mainly involves four steps: factor analysis test, factor extraction, named common factor, and factor score calculation. Compared with the analytic hierarchy process (ahp) and valuation methods, which are mostly used by domestic scholars in the research environment, the results of factor analysis are more objective and more reliable, because it overcomes the subjectivity of artificial determination of index weights.

\subsection{The content composition of the evaluation system}

\subsubsection{The framework of evaluation index system for attracting Talent}

Choosing useful evaluation indexes and constructing a set of relatively flexible and complete index system is the premise and basis of evaluating the environment correctly. Based on scientific principles, systematic principle, purposeful principle, and operational principle, based on referring to relevant literature and social survey, the objects of social questionnaire surveys are mainly job seekers in the talent exchange center. In combination with the author's thinking, an indicator system of evaluation environment is constructed (Table 1). The index system includes two primary indicators of social factors and natural factors, six secondary indicators, and 18 tertiary indicators.

\subsubsection{Analysis of the function principle of the second-level indicators of talent attraction evaluation}

(1) Social factors

1). Level of economic development

Among the indicators of economic development, sustained economic growth rate reflects the economic vitality of a city and is closely related to the potential demand for talents. Only when the economy continues to grow can new jobs be created. The higher the sustained economic growth rate, the more new jobs will be created, and the more attractive the talents will be. The lower the sustained economic growth rate, the fewer new jobs will be created, and the less attractive the talents will be.

2). living environment

Medical facilities involve all aspects. This paper selects the number of beds per 10,000 people as the representative of medical facilities. The better the medical facilities, the higher the medical level of the city, the more conducive to attracting talents the lower the medical facilities, the lower the medical level of the city, the less conducive to attracting talents.

3). Social security administration

The social security system is an essential factor in stabilizing talents and the basis of social security management. Only in a sound system, to ensure the basic living needs of talents. The more sound the social security system, the more stable the talent, the more efficiently the value of the talent. 
4) education and training opportunities

In the evaluation index of educational training opportunities, the proportion of investment in education is the performance of a city's talent strength and reflects the city's competitiveness to talents. The satisfaction degree of talent training needs reflects the city's attention to talent growth. The higher the degree of meeting the training needs of talents, the faster the growth of talents, which can not only stabilize the development of talents but, more importantly, improve the ability of potential talents and attract more talents.

(2) Natural environment

Environmental protection has an impact on the flow of talents, especially the flow of high-level talents. Air quality, water quality, and urban greening are the leading indicators of urban environmental protection. The higher the evaluation results of these indicators are, the better the natural environment of the city is, and the more favorable it is for attracting talents. The lower the evaluation results are, the worse the natural environment of the city is, and the more unfavorable it is for attracting talents.

(3) Cultural factors

The number of scientific research institutions, expenditures, and patent applications is an important indicator to reflect the scientific and technological innovation atmosphere in cities. The larger the number of scientific research institutions and the higher the investment intensity, the higher the city provides more opportunities for scientific and technological innovation for talents, and the higher space for talents to play, which is conducive to attracting talent

Table 1 index system of evaluating environment

\begin{tabular}{|c|c|}
\hline Composite indicator & Factor \\
\hline \multirow[t]{3}{*}{ Economic development environment $B_{1}$} & Sustained economic growth rate $C_{1}$ \\
\hline & Employee wage growth rate $C_{2}$ \\
\hline & GDP per capita $C_{3}$ \\
\hline \multirow[t]{3}{*}{ The living environment $B_{2}$} & Housing conditions $C_{4}$ \\
\hline & Medical facilities $C_{5}$ \\
\hline & Traffic conditions $C_{6}$ \\
\hline \multirow[t]{2}{*}{ Social security environment $B_{3}$} & Social insurance coverage $C_{7}$ \\
\hline & Social security $C_{8}$ \\
\hline \multirow[t]{3}{*}{ Education environment $B_{4}$} & Education investment status $C_{9}$ \\
\hline & Number of higher education institutions $C_{10}$ \\
\hline & Number of social training institutions $C_{11}$ \\
\hline \multirow[t]{3}{*}{ Natural environment $B_{5}$} & Air quality $C_{12}$ \\
\hline & Water quality $C_{13}$ \\
\hline & Urban greening $C_{14}$ \\
\hline \multirow[t]{4}{*}{ Technological innovation environment $B_{6}$} & Number of research institutions $C_{15}$ \\
\hline & Proportion of R\&D expenditure $C_{16}$ \\
\hline & Number of patents filed. $C_{17}$ \\
\hline & Number of high-tech enterprises $C_{18}$ \\
\hline
\end{tabular}


Table 2 Symbol Description

\begin{tabular}{|c|c|c|c|}
\hline Symbolic & explanation & Symbolic & explanation \\
\hline$C_{1}$ & $\begin{array}{l}\text { The comprehensive GDP growth } \\
\text { rate in the past two years }\end{array}$ & $C_{10}$ & $\begin{array}{l}\text { Number of regular institutions of } \\
\text { higher learning (institutions) }\end{array}$ \\
\hline$C_{2}$ & $\begin{array}{l}\text { The average annual salary growth } \\
\text { rate of on-the-job employees in the } \\
\text { past two years }\end{array}$ & $C_{11}$ & $\begin{array}{l}\text { Number of training institutions (the } \\
\text { directory of training institutions shall } \\
\text { prevail) }\end{array}$ \\
\hline$C_{3}$ & $\begin{array}{l}\text { Create regional wealth per capita } \\
\text { (yuan/person) }\end{array}$ & $C_{12}$ & $\begin{array}{c}\text { The number of days better than the } \\
\text { national level } 2 \text { good standard }\end{array}$ \\
\hline$C_{4}$ & $\begin{array}{l}\text { Per capita living area and housing } \\
\text { affordability }\end{array}$ & $C_{13}$ & $\begin{array}{l}\text { Industrial wastewater discharge up to } \\
\text { standard }\end{array}$ \\
\hline$C_{5}$ & There are beds per thousand people. & $C_{14}$ & Green space per capita \\
\hline$C_{6}$ & Road area per capita $\left(m^{2}\right)$ & $C_{15}$ & $\begin{array}{c}\text { Number of research institutions } \\
\text { (number) }\end{array}$ \\
\hline$C_{7}$ & $\begin{array}{l}\text { The proportion that on-the-job } \\
\text { worker attends all kinds of insurance }\end{array}$ & $C_{16}$ & $\begin{array}{l}\text { The proportion of R\&D expenditure } \\
\text { in GDP }\end{array}$ \\
\hline$C_{8}$ & $\begin{array}{l}\text { The number of criminal cases } \\
\text { recorded in the past two years has } \\
\text { decreased. }\end{array}$ & $C_{17}$ & $\begin{array}{l}\text { Average number of invention patent } \\
\text { applications accepted per 100,000 } \\
\text { people }\end{array}$ \\
\hline$C_{9}$ & $\begin{array}{l}\text { Education expenditure per capita } \\
\text { (yuan/person) }\end{array}$ & $C_{18}$ & $\begin{array}{l}\text { Ownership of high-tech enterprises } \\
\text { (individual) }\end{array}$ \\
\hline$H_{j}$ & $\begin{array}{l}\text { Macro comprehensive indicators of } \\
\text { urban environmental quality }\end{array}$ & $Z_{c}$ & $\begin{array}{c}\text { Average monthly wage growth over } \\
\text { the next five years as predicted by } \\
\text { Mr. Markov }\end{array}$ \\
\hline$Z_{y}$ & $\begin{array}{l}\text { Job seekers expect average monthly } \\
\text { salary increases over the next five } \\
\text { years. }\end{array}$ & $R_{c}$ & $\begin{array}{l}\text { Comprehensive evaluation of talent } \\
\text { attraction }\end{array}$ \\
\hline$B_{1}$ & $\begin{array}{l}\text { Comprehensive indicators of the } \\
\text { level of economic development }\end{array}$ & $B_{2}$ & $\begin{array}{l}\text { A comprehensive indicator of the } \\
\text { state of the living environment }\end{array}$ \\
\hline$B_{3}$ & $\begin{array}{c}\text { Comprehensive indicators of social } \\
\text { security management }\end{array}$ & $B_{4}$ & $\begin{array}{c}\text { A comprehensive indicator of } \\
\text { educational attainment }\end{array}$ \\
\hline$B_{5}$ & $\begin{array}{l}\text { Comprehensive indicators of the } \\
\text { state of the natural environment }\end{array}$ & $B_{6}$ & $\begin{array}{l}\text { A comprehensive indicator of the } \\
\text { climate of scientific and } \\
\text { technological innovation }\end{array}$ \\
\hline
\end{tabular}

\subsubsection{Factor analysis test}

Before factor analysis, it is necessary to determine whether the original variables are suitable for factor analysis. Generally, the correlation coefficient matrix and the sphericity test of KMO and butler are used to test the 18 three-level indicators of the original samples by SPSS16.0, of which table 3 and table 4 are the tests of the three indicators of the level of economic development.

Through the observation of table 3 , it can be seen that the correlation coefficient among all indicators is high, and the linear relationship is active, which can extract common factors and is suitable for factor analysis.

It can be seen that the KMO test value is 0.875 , and the butler ball physical examination result shows that its approximate chi-square distribution value is 253.634 , and the significance probability reaches 0.01 , less than 0.05 , under the condition of 66 degrees of freedom. According to the standard given by the statistician Kaiser, the original samples have a significant correlation of tertiary indicators and many common factors among variables, so it is suitable for factor analysis. 
Table 3 Correlation Coefficient Matrix

\begin{tabular}{c|c|c|c}
\hline & $\begin{array}{c}\text { Correlation Coefficient Matrix } \\
\text { economic growth } \\
\text { rate }\end{array}$ & $\begin{array}{c}\text { Employee wage } \\
\text { growth rate }\end{array}$ & GDP per capita \\
\hline $\begin{array}{c}\text { Sig Sustained economic } \\
\text { growth rate }\end{array}$ & 1.000 & 0.825 & 0.855 \\
\hline Employee wage growth rate & 0.825 & 1.000 & 0.834 \\
\hline GDP per capita & 0.855 & 0.834 & 1.000 \\
\hline
\end{tabular}

Through the observation of table 3 , it can be seen that the correlation coefficient among all indicators is high, and the linear relationship is active, which can extract common factors and is suitable for factor analysis.

It can be seen that the KMO test value is 0.875 , and the butler ball physical examination result shows that its approximate chi-square distribution value is 253.634 , and the significance probability reaches 0.01 , less than 0.05 , under the condition of 66 degrees of freedom. According to the standard given by the statistician Kaiser, the original samples have a significant correlation of tertiary indicators and many common factors among variables, so it is suitable for factor analysis.

\section{Result and Explain}

According to the results, KMO test values were all greater than 0.75 , and butler ball physical examination results showed that the significance probability was less than 0.05 . According to the standard given by the statistician Kaiser, the indicators of the original sample are significantly correlated, and there are many common factors among variables, so it is suitable for factor analysis. Finally, the regression method[3] is used to calculate the factor score coefficient matrix.

In summary, the factor score function is integrated as follows

$$
\begin{array}{r}
B_{1}=0.341 C_{1}+0.321 C_{2}+0.252 C_{3} \\
B_{2}=0.218 C_{4}+0.378 C_{5}+0.310 C_{6} \\
B_{3}=0.491 C_{7}+0.501 C_{8} \\
B_{4}=0.376 C_{9}+0.262 C_{10}+0.281 C_{11} \\
B_{5}=0.376 C_{12}+0.262 C_{13}+0.281 C_{14} \\
B_{6}=0.298 C_{15}+0.210 C_{16}+0.245 C_{17}+0.220 C_{18}
\end{array}
$$

Based on the analysis results, we put forward three Suggestions

First, strengthen the construction of industrial economic environment and improve the level of economic development.

Second, improve the urban environment and optimize the cultural environment

Third, optimize the growth conditions of employers and improve the professional market environment

\section{References}

[1] Ehab E Georgy, Eloise Cj Carr, Alan C Breen. Back pain management in primary care: development and validity of the Patients' and Doctors' Expectations Questionnaire. Quality in Primary Care, 2013, 21(2):113-122.

[2] Zhang Yanjun, Yang Xiaodong, Liu Yi, Zheng Dayuan, Bi Shujun. Research on the Frame of Intelligent Inspection Platform Based on Spatio-temporal Data. Computer \& Digital Engineering, 2019, 47(03): 616-619+637. 
[3] Maxwell, Gillian A, Ogden, Susan M, Broadbridge, Adelina. Generation $\mathrm{Y} \backslash$ "s Career Expectations and Aspirations: Engagement in the Hospitality Industry. Journal of Hospitality \& Tourism Management, 17(1):53-61.

[4] MS Susan Diamond Smith RDH, Med Darlene Duncan RDH, Carol Tresolini PhD, et al. Managed care organizations: Requirements and expectations for continuing education. Journal of Continuing Education in the Health Professions, 2005, 19(1):5-15.

[5] Gürkan A C. Visually Disabled Athletes' Reasons of Starting Sport and Their Expectations in Turkey. 2016, 11(6):1303-1317.

[6] Yi Liu, Jiawen Peng, and Zhihao Yu. 2018. Big Data Platform Architecture under The Background of Financial Technology: In The Insurance Industry As An Example. In Proceedings of the 2018 International Conference on Big Data Engineering and Technology (BDET 2018). ACM, New York, NY, USA, 31-35.

[7] Varshavskii, A. E.|Vinokurova, N. A.|Nikonova, M. A. The Scientific Pedagogical Cadres of Russia: Quality of Life, Moods, and Expectations. 2011, 53(12):67-81.

[8] Plooy P D. Refinement of a horticultural consultants service offering for producers in the South African deciduous fruit industry using service-dominant logic as a frame of reference. 2015. 